\title{
LOJALNOŚĆ PRACOWNIKA: TRWAŁA WARTOŚĆ CZY ANACHRONICZNA CNOTA?
}

ABSTRACT. Lewicka-Strzałecka Anna, Lojalność pracownika: trwała wartość czy anachroniczna cnota? [Employee loyalty: anachronistic virtue or real value?] edited by W. Banach - „Człowiek i Społeczeństwo", vol. XXXVIII, Poznań 2014, pp. 147-164, Adam Mickiewicz University Press. ISBN 978-83-232-2791-5. ISSN 0239-3271.

The article tries to answer the question whether employee's loyalty has any sense in the present day reality, when people change their job much more often than ever before and firms can appear and disappear very quickly. As the notion of loyalty is complex and polysemous, the first part of the article is devoted to the philosophical reflection on this issue. Next, the main arguments in the discussion on the employee's loyalty are reconstructed and the pattern of loyal employees based on managerial experience is shown. This leads to the conclusion that there is no universal answer to the question about the sense of employee's loyalty because it depends on the meaning of the term of loyalty and specific attributes of the organization for which the employee works. However, in some circumstances loyalty has the potential to contribute significantly to the employee's fulfillment and to enhance the economic results of the organization. The main challenge for researchers is to identify these circumstances and conditions.

Anna Lewicka-Strzałecka, Instytut Filozofii i Socjologii PAN, ul. Nowy Świat 72, 00-330 Warszawa, Poland.

\section{WSTĘP}

Lojalność pracowników, jak podkreśla wielu przedsiębiorców i menedżerów, ma zasadnicze znaczenie dla realizacji strategii firmy i jej długofalowych osiągnięć ${ }^{1}$. Oczywiście, zarówno wspomniane opinie, jak i wyniki

1 Tę opinię potwierdzają badania, np. raport Walkera pokazuje, że lojalni pracownicy w znacznie większym stopniu przyczyniają się do sukcesu firmy niż pozostali, zaś wieloletnie analizy prowadzone przez firmę Aon Hewitt wykazały zależność między poziomem wskaźnika zaangażowania w firmie a stopą całkowitego zwrotu dla akcjonariuszy, cyt. za: I. Świątek-Barylska, Lojalność pracowników wspótczesnych organizacji. Istota i elementy składowe, Wydawnictwo Uniwersytetu Łódzkiego, Łódź 2013, s. 83. 
badań należy traktować z pewną ostrożnością, ponieważ samo pojęcie lojalności jest wielowymiarowe, sytuacyjnie uwarunkowane i historycznie zmienne. Tradycyjnie rozumiana lojalność pracowników bywa utożsamiana ze swoistą wiernością wobec organizacji, przejawiającą się w długotrwałym zatrudnieniu i gotowości pozostawania w niej w dobrym i złym czasie. Jednak owa wierność bywa obecnie trudna do dochowania, kiedy zmiany cywilizacyjne i współczesne realia gospodarcze w istotny sposób wpływają na rodzaj i siłę powiązania człowieka z miejscem pracy, głównie rozluźniając i osłabiając te powiązania. Coraz rzadszy staje się model pracy przez całe życie w jednej firmie, ludzie zatrudniają się i zwalniają wielokrotnie w czasie swojej aktywności zawodowej, zmieniają nie tylko pracodawcę, ale i role zawodowe ${ }^{2}$. Cykl życia firm ulega ciągłemu skróceniu, los żadnej z nich nie jest pewny i zależy od trudno przewidywalnych fluktuacji w systemie prawnym, politycznym i gospodarczym.

Innowacje będące motorem rozwoju gospodarczego $\mathrm{z}$ jednej strony sprzyjają powstawaniu nowych firm i nowych szans na osobistą karierę, ale z drugiej - powodują konieczność redukcji zatrudnienia, czy wręcz upadek firm istniejących, a co za tym idzie - załamanie wielu indywidualnych ścieżek zawodowych. Przewagę konkurencyjną zdobywają te firmy, które potrafią łatwo dostosować się do zmiennego otoczenia, co między innymi polega na szybkim pozbyciu się zbędnego personelu i pozyskaniu takiego, który w danej sytuacji jest przydatny. Pojawia się wiele nowych, elastycznych form zatrudnienia. Jeżeli zawierane są kontrakty, to na krótki okres, liczne formy outsourcingu wzmacniają poczucie niepewności i tymczasowości zatrudnienia. Sprzyja to mobilności ludzi, ale jednocześnie rozluźnia wzajemne związki między pracownikami, relacje między pracownikami i przełożonymi, a także między pracownikami i firmą. Wiele kontaktów służbowych przybiera charakter zdepersonalizowany i bywa przenoszonych do przestrzeni wirtualnej. Kurczy się przestrzeń dla nieprzymuszonej troski pracowników o dobro organizacji, ponieważ coraz więcej powinności pracowniczych występuje w postaci sformalizowanych obowiązków, których zaniedbanie skutkuje ściśle określonymi sankcjami dyscyplinarnymi. Ścisłe wytyczne obowiązują w zakresie troski o jakość produktów, bezpieczeństwo

2 Dane empiryczne wskazują, że jedno pokolenie wstecz pracownicy amerykańscy zmieniali miejsce zatrudnienia średnio dwu- lub trzykrotnie w ciągu swojego życia, obecnie czynią to dziesięcio-, dwunastokrotnie. Zob. W. Altman, Whatever Happened to Employee Loyalty?, „Engineering \& Technology” 2008, vol. 3, iss. 6, April. Chociaż brakuje tego typu danych, które byłyby reprezentatywne dla polskiego rynku pracy, to pewne cząstkowe wyniki zdają się potwierdzać ogólną tendencję do skracania czasu zatrudnienia $\mathrm{w}$ jednym miejscu, zob. Ł. Pokrywka, Dtugość zatrudnienia u pracodawcy w Polsce, http://rynekpracy.pl/artykul.php/ typ.1/kategoria_glowna.10/wpis.522 [dostęp: 20.12.2013]. 
pracy czy własność firmy, wykonywania poleceń służbowych, zakazu konkurencji. W niektórych organizacjach pojawia się nawet obowiązek ujawniania nadużyć wewnątrz firmy, czyli wewnętrznego whistleblowingu. Istotną rolę $\mathrm{w}$ relacjach pracowników $\mathrm{z}$ organizacją odgrywa upowszechnienie instytucji kredytu, który staje się instrumentem władzy pracodawcy nad pracownikiem, ograniczającej coraz bardziej zakres wolnych decyzji ludzi w sferze zawodowej. Wszystko to oznacza, że coraz mniej jest miejsca dla zaangażowania organizacyjnego pracowników, a dobrowolna identyfikacja człowieka z miejscem pracy zdaje się odchodzić do lamusa. W tych zmieniających się dynamicznie warunkach pojawia się pytanie o to, czy lojalność pracownicza ma jeszcze jakiś sens. W kontekście refleksji filozoficznej nad pojęciem lojalności spróbuję odtworzyć istotę sporu o sens lojalności pracowniczej, zidentyfikować główne wymiary tego złożonego konstruktu pojęciowego i w końcu odnieść go do pewnych rekomendacji praktycznych.

\section{FILOZOFICZNE WYMIARY LOJALNOŚCI}

Lojalność jako pojęcie i idea od dawna była przedmiotem zainteresowania pisarzy, psychologów, psychiatrów, socjologów i politologów. Stosunkowo niewiele interesowała filozofów, aż do początku ubiegłego wieku, kiedy to amerykański filozof Josiah Royce opublikował dzieło The Philosophy of Loyalty, które zapoczątkowało szeroką filozoficzną refleksję nad lojalnością i ukształtowało nurt dalszych debat ${ }^{3}$. Poszukując warunków moralnie wartościowego życia, Royce uznał, że muszą one wyjść poza postulat posłuszeństwa konwencjonalnej moralności i sprawiać, by działania człowieka były częścią jego życiowego planu służącego realizacji wartościowych celów. Takie cele nie mogą być efektem przelotnych impulsów i chwilowych pragnień jednostki, ale powinny bazować na zbiorowym doświadczeniu i służyć dobru wspólnoty. Warunkiem ich urzeczywistnienia jest współdziałanie wielu podmiotów w dłuższym czasie, toteż jednostka, która świadomie i dobrowolnie uznała, że jej życiowe cele mieszczą się w pewnej społecznie ważnej sprawie, powinna sprzymierzyć się ze wszystkimi, których cele również tej sprawie służą. Lojalność, zdaniem Royce'a, polega na poświęceniu się dla tej sprawy, zarówno w sferze wolicjonalnej, jak i działaniowej. Stanowi ona elementarną cnotę, podstawowy obowiązek, z którego można wywieść inne powinności moralne. Wielość takich lojalności składa się na moralnie godne życie człowieka. Jednocześnie zdarza się, że poszczególne lojalności są ze sobą w konflikcie i pojawia się problem wyboru między nimi.

${ }^{3}$ Zob. J. Royce, The Philosophy of Loyalty, Vanderbilt University Press, Nashville 1905. 
Skoro lojalność sama w sobie ma być wartością, to jak stwierdzić, która jest bardziej cenna moralnie? Twórca teorii lojalności uważa, że należy odrzucić taką lojalność, która służy interesowi pewnych grup, szkodząc jednocześnie innym grupom bądź jednostkom, czy wręcz całemu społeczeństwu. Tej 'grabieżczej lojalności' (predatory loyalty) przeciwstawia 'prawdziwą lojalność' (true loyalty) zorientowaną maksymalnie szeroko - na dobro rodzaju ludzkiego, pozostawiającą poza swoim zasięgiem partykularne cele i grupy, które im służą. Kryterium oceny słuszności działań ma być ‘lojalność wobec lojalności' (loyalty to loyalty) zalecająca takie działania, które służą zachowaniu, wzmocnieniu i obronie prawa każdej jednostki do poczucia prawdziwej lojalności. Jak zauważają krytycy Royce'a, ideał prawdziwej lojalności nakazujący jednostce nieustanną weryfikację zgodności uznanych przez nią poszczególnych lojalności z uniwersalnym dobrem jest niemożliwy do urzeczywistnienia. Lojalności te skierowane są ku sprawom lub społecznościom, które są węższe lub szersze, ze swej istoty ograniczone w czasie i przestrzeni, a więc nie mogą być uniwersalne.

Royce'a teoria lojalności stanowi punkt odniesienia dla dalszych prac filozoficznych, których autorzy zarówno rozbudowują samo pojęcie, jak i badają jego zakorzenienie w kulturze i praktyce społecznej. Ich wysiłki składają się na pewien zbiorowy ogląd lojalności, pokazujący odmienność rozstrzygnięć w kilku istotnych kwestiach. Pierwsza różnica dotyczy opinii na temat tego, ku czemu może być skierowana lojalność, czyli jej obiektów. Dla Johna Ladda lojalność zawsze jest relacją między osobami, między rodzicem i dzieckiem, między suwerenem i wasalem, między przyjaciółmi, i nie może być traktowana jako wierność jakiemuś abstrakcyjnemu dobru. Lojalność jest nieuchronnie związana z emocjami i interesami określonych osób, toteż błędem jest nakładanie na ludzi obowiązków niemających związku z rzeczywistością, przekraczających ich powinności wobec konkretnych ludzi ${ }^{4}$. Odmiennego zdania jest Milton Konvitz, który rozszerza krąg obiektów, ku którym może być skierowana lojalność, i utrzymuje, że mogą to być zasady, idee, sprawy, religie, narody, rządy, regiony itd. ${ }^{5}$ Ronald Duska uważa, iż relacja lojalności może także zachodzić między jednostką i grupą, między osobą i jej rodziną, zespołem, którego jest członkiem, krajem urodzenia, zamieszkania ${ }^{6}$. W tym kontekście na uwagę zasługuje lojalność jednostki wobec organizacji, w szczególności firmy, ponadto poja-

${ }^{4}$ Zob. J. Ladd, Loyalty, [w:] The Encyclopedia of Philosophy, vol. 5, ed. P. Edwards, Macmillan, New York 1967, s. 97.

${ }^{5}$ Por. M. Konvitz, Loyalty, [w:] Encyclopedia of the History of Ideas, vol. 3, ed. P.P. Wiener, Scribner's, New York 1973.

${ }^{6}$ Por. R.F. Duska, Whistleblowing and Employee Loyalty, [w:] Contemporary Issues in Business Ethics, eds J.R. Desjardins, J. McCall, Wadsworth, Belmont 2000, s. 167-172. 
wia się kwestia oczekiwania wzajemności od instytucjonalnego podmiotu. Argumentacja towarzysząca odmiennym rozstrzygnięciom tej kwestii jest, jak się zdaje, wariantem dyskusji o firmie jako podmiocie moralnym zdolnym do podejmowania i ponoszenia odpowiedzialności. Chociaż uwaga badaczy lojalności koncentruje się na człowieku jako głównym jej podmiocie, to warto zauważyć, że lojalność bywa czasem przypisywana zwierzętom, szczególnie psom. Niektórzy biologowie i psychologowie ewolucyjni traktują ją jako przekazywany genetycznie mechanizm adaptacyjny, swoistą więź służącą przetrwaniu.

Kolejną niezwykle istotną kwestią w teorii lojalności jest pytanie o to, czy lojalność jest wartością samą w sobie, czy też jej wartość zależy od obiektu lojalności. Jeżeli za Piotrem Sztompką traktujemy lojalność jako „powinność nienaruszania zaufania, jakim obdarzają nas inni, i wywiązywania się z podjętych zobowiązań"7, to zdaje się ona stanowić wartość autoteliczną. Powinność ta przechodzi test uniwersalizacji na tej samej zasadzie, na jakiej pozytywnie odpowiadamy na pytanie wynikające z Kantowskiego imperatywu kategorycznego o słuszność bezwzględnego dotrzymywania obietnic. Przy takim rozstrzygnięciu na negatywną ocenę moralną zasługuje każde sprzeniewierzenie się lojalności bez względu na ocenę jej przedmiotu przez zewnętrznego obserwatora. Jednocześnie bezwarunkowa wierność dochowywana osobie lub sprawie, wbrew losowym przeciwnościom, czasem $\mathrm{z}$ uszczerbkiem dla własnego interesu, zasługuje na uznanie, nawet wtedy, gdy osoba nie jest tego warta, a sprawa wątpliwa czy skazana na przegraną.

Na względną ocenę lojalności wskazuje Maria Ossowska, zauważając, że może ona zależeć od przedmiotu lojalności. „Powiedzieć o kimś, że jest lojalnym obywatelem, to czasem wyraz uznania za skrupulatne wypełnianie wszystkich obowiązków wobec państwa, kiedy indziej, np. wtedy gdy władza jest obca i narzucona, lojalność komuś przypisywana ma posmak oportunizmu albo serwilizmu" ${ }^{8}$. Może jednak zdarzyć się tak, iż ktoś autentycznie uznaje za swoją i akceptuje władzę, traktowaną przez zewnętrznego obserwatora jako obcą czy narzuconą, a wtedy jego posłuszeństwo tej władzy nie jest oportunizmem ani serwilizmem. Relatywizacja oceny lojalności do oceny jej przedmiotu prowadzi do wniosku, że lojalność nie zawsze jest cnotą, a dokładniej, że to samo rzetelne wywiązywanie się z obowiązków $\mathrm{w}$ jednych oczach jest naganne, a w innych godne pochwały. Na przykład lojalny członek mafii zasługuje na uznanie ze strony przywódcy, a w zwykłych ludziach budzi grozę.

7 P. Sztompka, Zaufanie, Znak, Kraków 2007, s. 36.

${ }^{8}$ M. Ossowska, Normy moralne, PWN, Warszawa 1970, s. 136. 
Niejednoznaczny status lojalności prowadzi do skrajnie różnych ocen zewnętrznego whistleblowingu, co widać szczególnie wyraziście na przykładzie Ryszarda Kuklińskiego czy Edwarda Snowdena. Kukliński, będąc oficerem Ludowego Wojska Polskiego, w latach 1971-1981 przekazał Amerykanom ponad 40 tys. stron najtajniejszych dokumentów dotyczących Polski, ZSRR i Układu Warszawskiego. Okazał nielojalność wobec organizacji, która mu zaufała, chcąc osłabić śmiertelnego wroga, za jakiego uważał państwo radzieckie. Jego postać budzi krańcowo różne oceny w polskim społeczeństwie. Dla jednych jest on zdrajcą, który złamał przysięgę i naraził swoich rodaków na śmiertelne niebezpieczeństwo, dla innych to bohater i altruista, który poświęcił karierę, pozycję społeczną, dobro i spokój rodziny dla ratowania ojczyzny przed totalitarnym reżimem. Snowden, były współpracownik NSA i CIA, ujawnił światowej opinii publicznej szczegóły programu PRISM służącego rządowi Stanów Zjednoczonych do kontroli milionów e-maili, czatów, rozmów na Skypie zarówno Amerykanów, jak i obcokrajowców oraz niebywały zakres inwigilacji ambasad i sojuszników tego kraju. Snowden okazał się nielojalny wobec macierzystych instytucji, ponieważ naruszył podjęte wobec nich zobowiązania, lecz jednocześnie ujawnił czynione przez nie zło. $Z$ jednej strony jest uznawany za zdrajcę, godnego pogardy kryminalistę zasługującego na ciężkie więzienie, $\mathrm{z}$ drugiej zaś uchodzi za śmiałka, który przeciwstawił się potężnej organizacji w obronie prywatności jednostek, naraził się na utratę spokojnej, dostatniej egzystencji, działając $w$ interesie publicznym. Oskarżyciele Snowdena zarzucają mu kradzież materiałów będących własnością amerykańskiego rządu, natomiast obrońcy utrzymują, że roszczenie władzy do własności ujawnionych przez niego materiałów jest problematyczne, ponieważ zostały one uzyskane bez wiedzy i przyzwolenia obywateli. Ujawniając tajne informacje wywiadowcze, Snowden szkodził swojemu krajowi, ale jednocześnie uświadomił opinii publicznej fakt i mechanizmy działania najpotężniejszego aparatu inwigilacji w dotychczasowej historii ludzkości. Lojalność wobec jednych wartości została okupiona nielojalnością wobec innych.

Mimo różnic w pojmowaniu lojalności wielu filozofów zgadza się, że stanowi ona istotny czynnik dla spełnienia się jednostki w najbardziej ogólnym wymiarze ludzkiego życia. John Ladd powiada, że osoba całkowicie pozbawiona jakichkolwiek lojalności jest w jakimś sensie ułomna jako moralny agent ${ }^{9}$. Bycie lojalnym oznacza posiadanie stabilnej tożsamości, która jest określana przez tę lojalność lub te lojalności oraz warunkuje narratywną strukturę życia jednostki. Brak jakichkolwiek lojalności oznacza życie od

${ }^{9}$ Zob. J. Ladd, op. cit. 
jednej preferencji do innej. Tę rolę lojalności w życiu człowieka doceniają nie tylko filozofowie, ale także zwykli ludzie, co przejawia się na przykład w ich przywiązaniu do klubów sportowych czy zespołów muzycznych. Masowość i siła takiego przywiązania zdają się potwierdzać tezę o istotnej roli lojalności w kształtowaniu tożsamości jednostki.

John Kleinig zauważa, że lojalność jako pewna charakterystyka człowieka stanowi na ogół wiązkę lojalności skierowanych ku różnym obiektom przyjaciołom, rodzinie, organizacjom, ojczyźnie, religii ${ }^{10}$. Nie jest to zatem jakaś uogólniona więź, lecz sieć powiązań, które w znaczący sposób identyfikują jednostkę i które zostały przez nią z tych czy innych względów zaakceptowane. Są one cenne same w sobie, ponieważ łączą ją z jej przyjaciółmi, jej krajem, jej zawodem, nie czyimkolwiek innym. Taka identyfikacja sprawia, że jednostka odczuwa mocno powodzenia i porażki obiektów swojej lojalności i jest gotowa dla nich podejmować ryzyko i ponosić ciężary finansowe oraz wszelkie inne konsekwencje.

Istotną dystynkcją $\mathrm{w}$ teorii lojalności jest rozróżnienie między lojalnością przeznaczoną (unchosen) i wybraną (chosen). Ta pierwsza kształtuje się w naturalnym procesie rozwoju i dojrzewania jednostki i jest skierowana ku obiektom tworzącym otoczenie, w którym przyszło jej żyć, czyli bliższej i dalszej rodzinie, małej i dużej ojczyźnie, religii, państwie. Lojalność wybrana opiera się na akcie świadomej i dobrowolnej decyzji o współuczestniczeniu w misji jakiejś organizacji, związku, firmy. Sens obiektów 'lojalności przeznaczonej' na ogół nie podlega weryfikacji, gdyż są one traktowane jako zadane i ich zakwestionowanie byłoby swoistą autodestrukcją. Na przykład nielojalność jednostki wobec własnej rodziny musi naruszać w jakimś stopniu tożsamość tej jednostki, konstytuowaną przez przynależność do takiej, a nie innej rodziny. Sens obiektów 'lojalności wybranej' będący efektem osobistych preferencji jednostki i racjonalnej argumentacji może być kwestionowany zarówno od wewnątrz, czyli przez osobę dokonującą takiego, a nie innego wyboru, jak i przez zewnętrznych obserwatorów.

Dla obu typów lojalności istnieje rozbudowane uzasadnienie funkcjonalne wynikające $\mathrm{z}$ poszukiwania, czemu normy lojalnościowe służą $\mathrm{w}$ praktyce i jak funkcjonują w życiu społecznym. Najważniejsze punkty tego uzasadnienia zrekonstruować można następująco. Po pierwsze, lojalność stanowi skuteczne narzędzie do podtrzymywania instytucji znaczących dla społeczeństwa ${ }^{11}$, spośród których wiele stopniowo zanika, na co zwracają uwagę

10 Zob. J. Kleinig, Loyalty, [w:] Stanford Encyclopedia of Philosophy, http://plato.stanford. edu/entries/loyalty/ [dostęp: 20.12.2013].

11 Ibidem. 
teoretycy instytucji. Sprzyja temu kierowanie się wyłącznie własnym interesem w wyborze organizacji, z którymi chcemy być związani, i porzucanie ich tylko dlatego, że kontynuowanie związku się nam nie opłaca. Lojalność może być mechanizmem powstrzymującym ten niekorzystny dla społeczeństwa proces dekonstrukcji instytucji cennych dla wspólnego dobra. Istota tego mechanizmu, zdaniem Alberta Hirschmana, polega na neutralizacji tendencji do rozstania najbardziej wyczulonych na jakość członków czy uczestników organizacji. Dzięki lojalności pozostaną oni związani z organizacją kierowani nadzieją, czy może raczej wyrozumowanym oczekiwaniem, że poprawę lub reformę da się osiągnąć od wewnątrz. „W ten sposób lojalność, jak najdalsza od wszelkiej irracjonalności, służyć może społecznie użytecznemu celowi zapobiegania rozkładowi przez kumulację, co często dzieje się wówczas, gdy brak jest barier na drodze do rozstania"12. Kleinig podkreśla, że lojalność nie tylko zapobiega upadkowi niektórych organizacji, ale może także sprzyjać rozwojowi najistotniejszych instytucji społecznych, czego przykładem są hojne donacje na uniwersytety ofiarowywane przez absolwentów.

Kolejną funkcją pełnioną przez lojalność w życiu społecznym jest podtrzymywanie zasady wzajemności mającej konstytutywne znaczenie dla rozwoju i funkcjonowania gatunku ludzkiego. Sytuacje, w których lojalność wynika z wdzięczności za otrzymane dobro, służą nie tylko utrwaleniu przekonania, że długi wdzięczności są spłacane, ale także upowszechniają wiarę, iż na lojalność można zasłużyć przez odpowiednie działania. Tego typu doświadczenia stanowią podstawę do opracowywania programów zorientowanych na kształtowanie postaw lojalnościowych członków organizacji.

I wreszcie, lojalność pełni ważną rolę w rozwoju człowieka jako istoty społecznej, kształtowanej dzięki takim, a nie innym relacjom z grupą. Lojalność wzbogaca ten rozwój i umożliwia zaspokojenie potrzeby przynależności i afiliacji będącej jedną z podstawowych potrzeb psychicznych człowieka. Warunkiem zaspokojenia tej potrzeby przez jednostkę jest nawiązywanie i podtrzymywanie pozytywnych kontaktów i współpracy z innymi. Brak jakichkolwiek lojalności w życiu człowieka skazuje go na samotność i alienację, stwarza poczucie lęku oraz sprawia, że cele życiowe są trudno osiągalne lub niemożliwe do realizacji.

12 A. Hirschman, Lojalność, krytyka, rozstanie. Reakcje na kryzys państwa, organizacji i przedsiębiorstwa, przeł. J. Kochanowicz, I. Topińska, Fundacja im. Stefana Batorego, Znak, WarszawaKraków 1995, s. 80. 


\section{SPÓR O KSZTAŁT I SENS LOJALNOŚCI PRACOWNIKA}

Szczególną formę lojalności stanowi lojalność pracownika będąca przedmiotem zasadniczo rozbieżnych poglądów wśród etyków biznesu. Niektórzy autorzy widzą sens w kultywowaniu tej wartości13, inni całkowicie ją negują ${ }^{14}$. Jeszcze inni dopuszczają ją tylko w pewnych przypadkach ${ }^{15}$. Pfeiffer uważa, że jest ona obowiązkiem tylko wtedy, gdy wynika z obietnicy ${ }^{16}$, uznaje lojalność tylko wobec pracodawcy, którym jest społeczność17, zaś Ewin - wtedy gdy pracodawca służy celom, które są ważne społecznie ${ }^{18}$. Elegido uważa, że w pewnych warunkach lojalność stwarza szansę na samorealizacje pracownika ${ }^{19}$. Źródłem wielu $\mathrm{z}$ tych rozbieżności jest nie tylko charakterystyczna dla nauki różnorodność poglądów i założeń do prowadzonych badań i analiz, ale także zmiany zachodzące w firmach, ich otoczeniu i pracownikach ${ }^{20}$.

Lojalność rozumiana jako długotrwały związek pracownika z firmą jest, jak się zdaje, w opozycji do tak pożądanych cech nowoczesnych organizacji, jak zmienność, mobilność i elastyczność. Chociaż wspomniane tendencje niewątpliwie ograniczają zakres czasowy tego związku, to nie muszą całkowicie eliminować lojalności jako ważnej charakterystyki stosunków pracy, ponieważ pojęcie to ma znacznie szerszy zakres, zarówno w literaturze przedmiotu, jak i w opinii menedżerów oraz samych pracowników. Oprócz podtrzymywania relacji z firmą przez dłuższy czas lojalność pracownicza może wyrażać się na wiele innych sposobów. Są to takie zachowania i postawy, jak: gotowość do poświęcenia własnych celów dla dobra firmy, unikanie zewnętrznej krytyki, dzielenie się wiedzą i umiejętnościami zdobytymi

13 Por. D. Shah, 7 Qualities of a truly loyal employee, http://www.linkedin.com/today/ post/article/20130723160110-658789-7-qualities-of-a-truly-loyal-employee, [dostęp: 15.01.2014]; D. Mele, Loyalty in Business: Subversive Doctrine or Real Need?, „Business Ethics Quarterly" 2001, vol. 11, iss. 1, s. 11-26; J. Corvino, Loyalty in Business?, "Journal of Business Ethics" 2002, vol. 41, iss. 1-2, s. 79-185.

14 Por. M. Baron, The Moral Status of Loyalty, [w:] Ethical Issues in Engineering, ed. D. Johnson, Prentice Hall, Englewood Cliffs 1991; R.F. Duska, op. cit.

${ }^{15}$ M. Hajdin, Employee Loyalty: An Examination, „Journal of Business Ethics" 2005, vol. 59, s. $259-280$

16 R.S. Pfeiffer, Owing Loyalty to One's Employer, „Journal of Business Ethics" 1992, vol. 11, s. 535-543.

17 G.D. Randels Jr., Loyalty, Corporations and Community, „Business Ethics Quarterly” 2001, vol. 11, s. 27-39.

18 R.E. Ewin, Corporate Loyalty: Its Objects and Its Grounds, "Journal of Business Ethics" 1993, vol. 12, no. 5, s. 387-396.

19 J.M. Elegido, Does it Make Sense to be a Loyal Employee?, "Journal of Business Ethics” 2013, vol. 116, no. 3, s. 495-511.

${ }^{20}$ Zob. I. Świątek-Barylska, op. cit. 
$\mathrm{w}$ firmie $\mathrm{z}$ innymi pracownikami, zaangażowanie $\mathrm{w}$ wykonywaną pracę, zachowanie tajemnicy służbowej, sygnalizowanie problemów pojawiających się w pracy, troska o klienta itd. Lojalność pracownika wobec firmy może być również odczuwana i praktykowana po ustaniu stosunku pracy. Z drugiej strony podtrzymywanie przez długi czas relacji pracowniczej nie zawsze dowodzi lojalności, gdyż czasem wynika z osobistych kalkulacji.

Wymienione wyżej, a także inne wskazywane w literaturze wymiary lojalności w syntetyczny sposób ujmuje definicja zaproponowana przez Juana Elegida. Autor ten rozumie lojalność pracownika jako świadome działanie $\mathrm{w}$ najlepszym interesie pracodawcy, nawet kosztem własnego interesu, działanie wykraczające poza powinności wynikające z prawa czy moralności ${ }^{21}$. W tym ujęciu lojalność jest cnota, której rozwijanie i praktykowanie przyczynia się do samorealizacji jednostki. Lojalność to nie sentyment, uczucie czy pasja, ale świadomy wybór. Nie oznacza to, że lojalność jest zupełnie oderwana od emocji, ponieważ w wielu przypadkach konstytuująca ją przemyślana decyzja jest motywowana uczuciem przywiązania.

Adresatami lojalności pracownika mogą być konkretne osoby - liderzy, przełożeni, koledzy, grupy osób - oddziały, zespoły zadaniowe, a także obiekty abstrakcyjne, takie jak misja firmy, zasady, wartości. Lojalność wobec pracodawcy nie musi być ekskluzywna, czyli lojalność wobec pewnego podmiotu nie wyklucza lojalności wobec innych. Pracodawca rozumiany jest szeroko, oprócz organizacji biznesowej może to być placówka naukowa, urząd, placówka służby zdrowia, organizacja pozarządowa, Kościół. To rozszerzenie jest dosyć istotne, ponieważ wiele argumentów przeciw pracowniczej lojalności ma swoje źródło w sferze działalności biznesowej, natomiast okazują się one nietrafne w innych sferach.

Lojalność pracownika nie ma charakteru dychotomicznego, zmuszającego do wyboru między pełnym oddaniem, którego wymagali Royce czy Ladd, z jednej strony i niechęcią z drugiej. Stanowi ona raczej pewne kontinuum; lojalny pracownik nie musi poświęcać wszystkiego dla swojego pracodawcy, rezygnując z niektórych korzyści własnych, może być lojalny w pewnym stopniu. Nie musi być zatem tak, że pracownik, który nie jest lojalny w sensie całkowitego poświęcenia się dla firmy, jest nielojalny. Jak zauważa Pfeiffer, ktoś może nienagannie wykonywać swoje obowiązki zawodowe i być cenionym pracownikiem, ale jednocześnie poszukiwać lepszego zatrudnienia, co nie musi oznaczać, że jest nielojalny.

${ }^{21}$ Zob. J.M. Elegido, op. cit. 
Elegido, podobnie jak inni autorzy22, traktuje lojalność jako działanie $\mathrm{w}$ najlepszym interesie pracodawcy, ale zaznacza, że nie jest to równoznaczne z zaspokajaniem wszystkich jego pragnień. Warto zauważyć, że $\mathrm{w}$ ten sposób pracownik zostaje jak gdyby wyposażony $\mathrm{w}$ moc orzekania o tym, co stanowi najlepszy interes pracodawcy, czyli lojalność może płynnie przechodzić w paternalizm. Rozmyta kategoria najlepszego interesu pracodawcy, wahająca się od interesu krótkoterminowego do długoterminowego, od finansowego do pozafinansowego, stwarza możliwość swobodnej interpretacji wielu działań jako lojalnych bądź nielojalnych.

Brak lojalności jest jednym z koronnych zarzutów stawianych pracownikom ujawniającym nieetyczne lub nielegalne działania swoich firm, czyli whistleblowerom. Zdaniem przywoływanego Ronalda Duski taki zarzut jest nieuprawniony, ponieważ wymaganie lojalności od pracowników nie ma sensu. Autor ten reprezentuje radykalne stanowisko głoszące, że lojalność jest czymś obcym w biznesie. Swoją tezę Duska uzasadnia następująco. Po pierwsze, twierdzi on, iż lojalność cechuje tylko takie relacje, w których ktoś poświęca swoje dobro na rzecz kogoś innego, nie oczekując za to żadnej nagrody, a przecież relacje $\mathrm{w}$ biznesie ze swojej natury nie są bezinteresowne. Ludzie zakładają i prowadzą firmy nie po to, by się wspierać czy realizować jakieś szczytne cele, ale by zarabiać pieniądze. Metafora przyrównująca firmę do rodziny jest błędna, ponieważ rodzina pomaga słabszym członkom, natomiast firma w trosce o swój finansowy wynik zwalnia mało wydajnych pracowników. Po drugie, zwykle uważa się, że lojalność wymaga wzajemności, tymczasem nie jest i nie powinien być czymś niezwykłym brak wzajemności firmy wobec oddanych jej pracowników. Ślepa lojalność pracownika wobec organizacji, która nie jest i nie może być lojalna wobec niego, gdyż nie jest podmiotem moralnym, nie ma sensu. Po trzecie, lojalność jest niezgodna z komercyjnym charakterem relacji pracownik - pracodawca, ponieważ oba podmioty tej relacji dążą do maksymalizacji swojej materialnej korzyści. Firma zatrudnia pracownika po to, by osiągać zysk, pracownik podejmuje pracę po to, by otrzymywać pensję. Poczuwanie się do lojalności wobec firmy jest równoznaczne z przypisaniem jej statusu osoby lub grupy urzeczywistniającej wysokie wartości. Zdaniem Duski jest to błędne założenie, gdyż firma nie jest osobą, ale instrumentem - i to szczególnym, gdyż służącym do osiągania zysków. Traktowanie firmy jako podmiotu moralnego zdolnego do podejmowania i ponoszenia odpowiedzial-

22 Por. J.R. Boatright, Ethics and the Conduct of Business, Prentice Hall, Upper Saddle River 2003; R. Larmer, Whistleblowing and Employee Loyalty, "Journal of Business Ethics" 1992, vol. 11, s. 125-128; J.A. Stieb, Clearing up the Egoist Difficulty with Loyalty, "Journal of Business Ethics" 2006, vol. 63, s. 75-87. 
ności oznacza postawienie jej wymagań, których nie może ona spełnić ze względu na swój instrumentalny charakter. Dlatego niesłusznie czuje się zdradzony pracownik, który poświęcał się dla swojej firmy i został z niej zwolniony $w$ ramach restrukturyzacji zatrudnienia. I wreszcie, lojalność jest niezgodna z przedmiotowym charakterem relacji pracownik - pracodawca, która jest podtrzymywana i rozwijana nie dla niej samej, lecz dla jakichś zewnętrznych celów. Pracownik wiąże się z organizacją A po to, by wykonywać jakąś pracę, za którą dostanie wynagrodzenie, ale jeżeli $w$ organizacji B znajdzie lepsze ku temu warunki, to może przejść do organizacji B, gdyż nie wiąże się $\mathrm{z}$ organizacją dla niej samej. Podobnie organizacja zatrudnia pracownika $X$ po to, by realizował dla niej określone zadania, ale jeżeli pracownik $Y$ będzie czynił to lepiej, to zatrudni $Y$, gdyż zatrudnia pracownika nie dla niego samego, ale dla zadania, które ma on wykonać.

Stanowisko Duski ze względu na swą wyrazistość przypomina, zarówno w treści, jak i w formie, Friedmana negację społecznej odpowiedzialności biznesu i podobnie jak słynna krytyka CSR, stało się punktem odniesienia do dalszej dyskusji nad sensem i kształtem lojalności pracowniczej. Rozmaite punkty widzenia przedstawiane $\mathrm{w}$ tej dyskusji, odnoszące się zarówno do możliwego rozumienia poszczególnych pojęć, jak i zmieniających się warunków funkcjonowania organizacji, podważają w istotny sposób argumenty Duski. Nie oznacza to jednak, że udało się znaleźć jakiś uniwersalny sens dla lojalności jako charakterystyki właściwej relacjom między pracownikiem i organizacją. Jak zauważa Elegido23, uniemożliwia to różnorodność tych relacji właściwa współczesnym stosunkom gospodarczym i społecznym. Maksymalnie zróżnicowany jest rodzaj wykonywanej pracy, począwszy od czynności czysto manualnych i powtarzalnych do bardzo trudnych zadań, wymagających ogromnej wiedzy i wysoko specjalistycznych kwalifikacji. Organizacje zatrudniające pracowników mogą być publiczne i prywatne, biznesowe i non-profit, duże i małe, mocno i słabo sformalizowane itd. Relacja między pracownikiem i organizacją jest również kształtowana przez kulturę, system prawny i sytuację gospodarczą danego kraju. Konsekwencją tej różnorodności jest niemożność uzasadniania ogólnych tez dotyczących lojalności. Można jednak pokazać, jak twierdzi Elegido, że w pewnych warunkach, w szczególności akceptowania przez pracownika celów i wartości realizowanych przez organizację, postawa lojalności stanowi dla niego szansę osiągnięcia poczucia spełnienia. Jednocześnie taka postawa wiąże się z ryzykiem bycia oszukanym i dlatego identyfikacja organizacji, wobec których warto być lojalnym, stanowi wyzwanie dla pracowników.

${ }^{23}$ Zob. J.M. Elegido, op. cit. 
Elegido nie tylko stawia tezę o pozytywnym wpływie lojalności pracownika na jego samorealizację, ale także podejmuje próbę konkretyzacji tej tezy, wskazując na kilka przejawów tego wpływu. Po pierwsze, lojalny pracownik ma wyższą motywację będącą istotnym czynnikiem psychicznego dobrostanu. Poziom motywacji zależy od stabilności emocjonalnej, a ta z kolei powiązana jest z lojalnością. Lojalność oznacza także, że pracownik identyfikuje się z celami swojego pracodawcy, a to wzmacnia chęć do pracy i sprawia, iż praca nie jest traktowana czysto instrumentalnie. Po drugie, lojalni pracownicy są bardziej wiarygodni i dzięki temu bardziej atrakcyjni dla pracodawców niż pracownicy nielojalni. Elegido podkreśla, że nie chodzi o to, by kształtować cnotę lojalności w celu podniesienia własnej atrakcyjności jako pracownika, ale by zakwestionować przekonanie podzielane szczególnie przez młodych ludzi, iż lojalność jest barierą w osiąganiu sukcesu zawodowego. Po trzecie, lojalni pracownicy przyczyniają się do powodzenia organizacji, a tym samym powiększają szanse na własny sukces. Organizacja zatrudniająca lojalnych pracowników może na nich delegować swoje prawa i upoważnienia, nie obawiając się, że zostaną one nadużyte dla partykularnych celów. Taka delegacja ma szczególne znaczenie w szybko zmieniającym się otoczeniu, w którym sukces zależy od natychmiastowej reakcji pracownika mającego bezpośredni kontakt ze zmianą. Lojalni pracownicy mogą być wyposażeni w informacje poufne, których nie ujawnią, lecz w stosownym momencie wykorzystają dla dobra firmy, mogą także przysłużyć się jej jako depozytariusze pamięci instytucjonalnej. Lojalny pracownik jest wartościowy dla firmy, ale zespół takich pracowników daje firmie przewagę konkurencyjną na rynku. Po czwarte, lojalni pracownicy ułatwiają rozwój nowym organizacjom i przetrwanie istniejącym, kreując i zachowując kapitał społeczny, ponieważ chronią wartościowe społeczne instytucje. Tym samym kreują szerokie otoczenie, przyjazne dla ich funkcjonowania i rozwoju. Po piąte, lojalność wobec pracodawcy poprawia relacje pracownika $\mathrm{z}$ innymi podmiotami. Sfera zawodowa jest jedną z ważniejszych sfer życia człowieka, toteż praktykowanie $w$ niej cnoty lojalności sprawia, że staje się ona trwałą dyspozycją jednostki sprzyjającą lepszemu jej funkcjonowaniu w rodzinie, małżeństwie, przyjaźni. Po szóste, lojalność pracownika może wzbogacić go przez rozszerzenie jego obszarów zainteresowań i świata wartości. Identyfikacja pracownika z firmą sprawia, iż postrzega on jej sukcesy i porażki jak swoje własne, przez co powiększa zakres spraw, które uważa za istotne w swoim życiu. Po siódme, lojalność pracownika $\mathrm{w}$ jakimś sensie integruje jego życie, gdyż redukuje jego podział na odrębne sfery, co jest charakterystyczne dla współczesności. W stopniu, $\mathrm{w}$ jakim nasze działania zmierzają ku różnym, niepowiązanym celom, nasze 
życie nie tworzy koherentnej historii i nie może być zrozumiane. Jeżeli jednak sukcesy organizacji, dla której pracujemy, są naszymi sukcesami, ta część zaangażowania i czasu, którą poświęciliśmy na pracę, zostaje włączona do historii naszego życia. Po ósme, lojalni pracownicy przyczyniają się do przekształcenia organizacji $\mathrm{w}$ realną wspólnotę dającą poczucie przynależności swoim członkom, udzielającą im wsparcia emocjonalnego i pomocy w praktycznych trudnościach. Taka wspólnota wzmacnia jakość społecznych interakcji oraz relacji interpersonalnych i możliwość przynależenia do niej jest szczególnie ważna $\mathrm{w}$ dzisiejszych czasach, kiedy słabną tradycyjne wspólnoty. Ostatnią, chociaż nie najmniej ważną, pozytywną charakterystyką lojalności pracowniczej jest jej inherentna wartość. Zaangażowanie przez dłuższy czas na rzecz pracodawcy, którego wartości się ceni, wkładanie wysiłku i angażowanie twórczego potencjału dla realizacji celów, które uważa się za ważne, jest cenne samo w sobie, nawet jeżeli cele nie zostaną osiągnięte.

Podkreślając, że lojalność ma w jego koncepcji charakter relatywny, Elegido odnosi się do poglądów kwestionujących słuszność wszelkiej lojalności wobec pracodawcy. Jeden $\mathrm{z}$ nich utrzymuje, że człowiek nie musi poszukiwać obiektu lojalności w pracy, gdyż poza nią istnieją sfery, z którymi może się identyfikować, takie jak jego profesja czy społeczność, i tam wartość lojalności może być pełniej realizowana. Nie negując tych możliwości, Elegido utrzymuje, iż błędem jest zapoznanie cnoty lojalności wobec pracodawcy, gdy okoliczności temu sprzyjają, ponieważ praca wypełnia istotną część życia człowieka. Innym argumentem przeciw lojalności jest to, że czyni ona pracownika słabszym $\mathrm{w}$ jego relacjach $\mathrm{z}$ pracodawcą, ponieważ skłania do poświęcenia własnego interesu na rzecz organizacji. Jednak relatywna koncepcja lojalności nie polega na bezwarunkowym poświęcaniu się, niezależnie od okoliczności, ale na takiej rezygnacji z pewnych, na ogół doraźnych, korzyści, dzięki której pracownik zyska w sferze wartości w postaci zwiększonej motywacji do pracy, mocniejszego charakteru i bardziej integralnego światopoglądu. Repliką na wspominany wyżej argument Duski o komercyjnym charakterze relacji między pracownikiem i organizacją wykluczającym względy pozamaterialne jest coraz powszechniej podzielany pogląd, iż zysk nie jest jedynym celem biznesu, przejawiającym się w różnych instrumentach społecznej odpowiedzialności biznesu. Z kolei niełatwy do zakwestionowania wydaje się pogląd Hajdina ${ }^{24}$, głoszący, że lojalność pracowników jest trudna do kultywowania w spółkach publicznych, które mogą być poddane zasadniczym reorganizacjom na skutek wrogiego przejęcia lub zmian $\mathrm{w}$ zarządzie. Zadania wykonywane przez lata przez tysiące ludzi mogą

${ }^{24}$ M. Hajdin, op. cit., s. 259-280. 
zostać odwołane lub zmienione w bardzo krótkim czasie, a korporacja jest jedynie formą ukształtowaną przez prawne uregulowania, do której może zostać włożona dowolna zawartość. $W$ takich przypadkach czujność pracowników chcących kultywować cnotę lojalności powinna być wyjątkowo wyostrzona. Przeciw lojalności wysuwa się również zarzut osłabiania krytycyzmu wobec przełożonych. Bezwzględna lojalność wobec pracodawcy może sprawić, że pracownik sprzeniewierza się własnym wartościom i przekonaniom, a nawet może prowadzić do tolerowania lub współuczestnictwa w działaniach nielegalnych czy nieetycznych. Jednak taki zarzut można postawić wobec każdej formy lojalności czy poświęcenia - nie tylko wobec pracodawcy - i jego uznanie oznaczałoby całkowitą deprecjację tej wartości w życiu społecznym.

\section{WZÓR LOJALNEGO PRACOWNIKA}

Refleksja na temat lojalności wobec organizacji jest obecna nie tylko w pracach filozofów i etyków biznesu, ale także w dyskusjach menedżerów i przedsiębiorców. Praktycy biznesu przyjmują intuicyjne rozumienie tego pojęcia i koncentrują się na określeniu wzoru lojalnego pracownika bazującego na obserwacji konkretnych zachowań. Dharmesh Shah²5, założyciel i jeden z prezesów HubSpot, wielkiej firmy marketingowej świadczącej usługi dla 10 tys. firm z pięćdziesięciu czterech krajów, opierając się na wieloletnim doświadczeniu w zarządzaniu setkami pracowników, zaproponował taki oto wzór. Tworzy go siedem standardów zachowań orzekających, że lojalni pracownicy:

1. Przedkładaja długofalowe cele organizacji nad doraźne korzyści (działaja perspektywicznie)

Często sądzi się, że lojalność polega na posłuszeństwie. Pewien rodzaj posłuszeństwa bywa bezmyślny i niepodający w wątpliwość żadnych poleceń, także gdy sięgają one szarej strefy, a nawet gdy naruszają zasady etyki lub prawa. Lojalny pracownik nie ogranicza się do ścisłego wykonywania poleceń, ale stara się działać w długofalowym interesie organizacji. Chociaż na krótką metę może wydawać się nielojalny, w dalszej perspektywie okazuje się, iż przejawia on wyższy poziom lojalności, ponieważ powstrzymując firmę od uzyskania doraźnych korzyści, chroni ją przed przyszłymi wielkimi stratami.

${ }^{25}$ D. Shah, 7 Qualities of a Truly Loyal Employee, http://www.linkedin.com/today/post/ article/20130723160110-658789-7-qualities-of-a-truly-loyal-employee [dostęp: 15.01.2014]. 
2. Inicjuja dyskusje, gdy inni tego nie czynia

Wielu pracowników obawia się przedstawiać swoje opinie lub odczucia w obecności innych, niektórzy nie czynią tego nawet prywatnie. Lojalni pracownicy przejawiają wrażliwość na problemy ludzi wokół siebie i pytają lub interweniują, gdy inni tego nie czynią. Wiedzą, że warunkiem powodzenia firmy jest, by kierownictwo wiedziało, co myślą pracownicy, i by pracownicy wiedzieli, co myśli kierownictwo. Pewien pracownik w czasie zebrania zadał pytanie dotyczące nowej inicjatywy. On sam znał te plany doskonale, ponieważ uczestniczył w ich przygotowaniu, ale wiedział, że wiele osób nie zainteresuje się nimi, dopóki nie będzie to ich bezpośrednio dotyczyło, i uznał, iż powinni poznać plany i opinie kierownictwa.

\section{Doceniaja innych pracowników}

Lojalni pracownicy przejawiają troskę o firmę, klientów, wypełnianie misji, mają poczucie, że pracują nie tylko dla siebie. Dlatego doceniają wysiłek i dokonania innych pracowników przyczyniających się do realizacji misji firmy. Pracownicy, którzy doceniają innych, szczególnie wtedy, gdy nie muszą tego robić, nie tylko przejawiają duże interpersonalne umiejętności, ale przyczyniają się do powodzenia firmy.

4. Przedstawiaja własne zdanie i odmienne opinie wewnatrz organizacji

Każda dobra firma inicjuje debatę i umożliwia wyrażenie różnych opinii. Każdy dobry przywódca skłania pracowników do zadawania pytań, dyskutowania, kwestionowania jego pomysłów. Ważenie pozytywnych i negatywnych stron poszczególnych decyzji, dopuszczanie konfliktowych opinii, wysłuchiwanie advocati diaboli jest stymulujące i prowadzi do lepszych rozwiązań. Lojalni pracownicy ujawniają własne opinie, nawet jeżeli nie są one po myśli kierownictwa, ponieważ zależy im na dobru firmy. Czasem też zajmują stanowisko niezgodne ze stanowiskiem kierownictwa.

\section{Popieraja stanowisko firmy $w$ debacie publicznej}

Po podjęciu decyzji przez firmę lojalni pracownicy akceptują ją na forum publicznym, nawet jeżeli prywatnie się z nią nie zgadzają. Nie traktują jej z przymrużeniem oka, popierają ją, jakby to było ich własne rozwiązanie, ponieważ dla lojalnego pracownika każde oficjalne stanowisko firmy staje się jego własnym. Niektórzy pracownicy niegodzący się z decyzjami firmy biernie lub czynnie starają się wykazać, że decyzje te są błędne. Natomiast prawdziwie lojalny pracownik, pomimo osobistych zastrzeżeń, czyni wszystko, by wdrożenie tych decyzji przyniosło jak najlepszy rezultat.

6. Starają się przekazać to, co przełożeni naprawdę powinni ustyszeć

Prawdziwie lojalny pracownik zdaje sobie sprawę, że kierownictwo powinno poznać prawdę o tym, co się dzieje w firmie, np. że jakaś inicjatywa 
nie jest właściwie wdrażana, popełnione zostały błędy. Ta prawda może nie być mile przyjmowana, ale $\mathrm{w}$ ostatecznym rachunku ona właśnie jest decydująca dla powodzenia firmy, jej pracowników, klientów. Warto jednocześnie podkreślić, że im większy dystans w hierarchii służbowej, tym mniejsze prawdopodobieństwo, iż pracownik będzie skłonny taką prawdę wyrazić wprost wobec przełożonego. Dlatego czasem wyraża ją pośrednio, np. przez milczenie, i mądry szef powinien umieć takie znaki odczytać.

\section{Odchodza, uprzedzając i pomagając znaleźć następce}

Prawdziwie lojalny pracownik jest zawsze niezwykle cenny. Często są to najlepsi pracownicy, toteż ostatnią rzeczą, jakiej chciałaby firma, jest ich odejście. Jednak niekiedy zdarza się, że chcą oni zmienić styl życia, założyć własną firmę lub gdzie indziej widzą szansę na swój rozwój. Kiedy ten czas nadchodzi, lojalny pracownik uprzedza i pomaga znaleźć kogoś odpowiedniego na swoje miejsce.

Przedstawiony wyżej przegląd poglądów na temat lojalności pracowników wskazuje, że jest to znacząca wartość we współczesnej gospodarce i życiu społecznym, chociaż rozumienie samego pojęcia lojalności i sposobów jej urzeczywistnienia jest zróżnicowane zarówno $\mathrm{w}$ teorii, jak i w praktyce. $\mathrm{Z}$ jednej strony uważa się, że lojalni pracownicy są najcenniejszym zasobem organizacji, źródłem jej przewagi konkurencyjnej na rynku, najważniejszym czynnikiem przeciwdziałającym kryzysom i wsparciem w sytuacji ich pojawienia się. Z drugiej strony lojalność sprowadzona do bezwzględnego posłuszeństwa może prowadzić do wypaczonego jej rozumienia, co znajduje odzwierciedlenie w przytaczanym przez Kleiniga powiedzeniu: „Kiedy organizacja oczekuje od pracownika właściwego postępowania, odwołuje się do jego uczciwości, kiedy chce, by zrobił coś złego, żąda od niego lojalności" 26 .

Nie istnieje jednoznaczna odpowiedź na pytanie o sens bycia lojalnym pracownikiem, ponieważ zależy ona zarówno od rozumienia pojęcia lojalności, jak i okoliczności funkcjonowania organizacji i jej specyfiki. Jednocześnie powyższe analizy wskazują, że kreowanie i podtrzymywanie lojalności między pracownikiem i organizacją stanowi szansę powodzenia dla obu stron tej relacji. Argumenty pokazujące, że pod pewnymi warunkami lojalność pracownika ma pozytywny wpływ na jego samorealizację, oraz przekonanie wielu praktyków biznesu, iż trwałość więzi może być istotnym źródłem sukcesu ekonomicznego, otwierają szerokie pole do badań nad lojalnością. Rozbieżność ogólnych tez dotyczących lojalności sugeruje koncentrację na określonych typach lojalności warunkowanych przez szczególne okoliczności.

${ }^{26}$ J. Kleinig, op. cit. 


\section{BIBLIOGRAFIA}

Altman W., Whatever Happened to Employee Loyalty?, „Engineering \& Technology” 2008, vol. 3, iss. 6, April.

Baron M., The Moral Status of Loyalty, [w:] Ethical Issues in Engineering, ed. D. Johnson, Prentice Hall, Englewood Cliffs 1991.

Boatright J.R., Ethics and the Conduct of Business, Prentice Hall, Upper Saddle River 2003.

Corvino J., Loyalty in Business?, "Journal of Business Ethics” 2002, vol. 41, iss. 1-2.

Duska R.F., Whistleblowing and Employee Loyalty, [w:] Contemporary Issues in Business Ethics, eds J.R. Desjardins, J. McCall, Wadsworth, Belmont 2000.

Elegido J.M., Does it Make Sense to be a Loyal Employee?, "Journal of Business Ethics" 2013, vol. 116 , no. 3 .

Ewin R.E., Corporate Loyalty: Its Objects and Its Grounds, "Journal of Business Ethics" 1993, vol. 12 , no. 5 .

Hajdin M., Employee Loyalty: An Examination, "Journal of Business Ethics” 2005, vol. 59.

Hirschman A., Lojalność, krytyka, rozstanie. Reakcje na kryzys państwa, organizacji i przedsiębiorstwa, przeł. J. Kochanowicz, I. Topińska, Fundacja im. Stefana Batorego, Znak, Warszawa-Kraków 1995.

Kleinig J., Loyalty, [w:] Stanford Encyclopedia of Philosophy, http://plato.stanford.edu/ entries/loyalty/ [dostęp: 20.12.2013].

Konvitz M., Loyalty, [w:] Encyclopedia of the History of Ideas, vol. 3, ed. P.P. Wiener, Scribner's, New York 1973.

Ladd J., Loyalty, [w:] The Encyclopedia of Philosophy, vol. 5, ed. P. Edwards, Macmillan, New York 1967.

Larmer R., Whistleblowing and Employee Loyalty, "Journal of Business Ethics” 1992, vol. 11.

Lipka A., Winnicka-Wejs A., Acedański J., Lojalność pracownicza, Difin, Warszawa 2012.

Mele D., Loyalty in Business: Subversive Doctrine or Real Need?, „Business Ethics Quarterly” 2001, vol. 11, iss. 1.

Ossowska M., Normy moralne, PWN, Warszawa 1970.

Pfeiffer R.S., Owing Loyalty to One's Employer, "Journal of Business Ethics" 1992, vol. 11.

Pokrywka Ł., Dtugość zatrudnienia u pracodawcy w Polsce, http://rynekpracy.pl/artykul. php/typ.1/kategoria_glowna.10/wpis.522 [dostęp: 20.12.2013].

Randels G.D. Jr., Loyalty, Corporations and Community, „Business Ethics Quarterly” 2001, vol. 11.

Royce J., The Philosophy of Loyalty, Vanderbilt University Press, Nashville 1905.

Schrag B., The Moral Significance of Employee Loyalty, "Business Ethics Quarterly” 2001, vol. 11.

Shah D., 7 Qualities of a Truly Loyal Employee, http://www.linkedin.com/today/post/ article/20130723160110-658789-7-qualities-of-a-truly-loyal-employee [dostęp: 15.01.2014].

Stieb J.A., Clearing up the Egoist Difficulty with Loyalty, "Journal of Business Ethics" 2006, vol. 63.

Sztompka P., Zaufanie, Znak, Kraków 2007.

Świątek-Barylska I., Lojalność pracowników wspótczesnych organizacji. Istota i elementy składowe, Wydawnictwo Uniwersytetu Łódzkiego, Łódź 2013. 